\title{
Pengaruh Keadilan Organisasi dan Leader Member Exchange terhadap Komitmen Organisasional pada Karyawan
}

\author{
Diny Atrizka, Chintya Fensiski, Dwi Septina Megawati, Febrianty \\ Wijaya, Windy
}

\author{
Fakultas Psikologi Universitas Prima Indonesia \\ email: diny.dinyrizk@gmail.com
}

\section{Artikel INFO \\ Diterima:21 Juni 2020 \\ Direvisi :29 sep 2020 \\ Disetujui: 17 Nov 2020}

DOI:

http://dx.doi.org/10.24014/ jp.v14i2.9799

\begin{abstract}
Abstrak
Komitmen organisasi merupakan salah satu elemen penting dalam keberhasilan sebuah perusahaan. Karyawan yang memiliki komitmen tinggi cenderung menunjukkan partisipasi yang sangat berpengaruh bagi kemajuan perusahaan. Tujuan dilakukannya penelitian ini adalah untuk menguji dan mengetahui pengaruh antara keadilan organisasi dan leader member exchange terhadap komitmen organisasional. Sampel penelitian terdiri dari 120 karyawan PT. Pasar Swalayan Maju Bersama dengan metode total sampling. Data penelitian dikumpulkan dengan menggunakan skala komitmen organisasional, skala keadilan organisasi, dan skala leader member exchange. Hasil penelitian menunjukkan bahwa terdapat pengaruh antara keadilan organisasi dan leader member exchange terhadap komitmen organisasional. Hasil penelitian menunjukkan bahwa terdapat pengaruh positif antara keadilan organisasi terhadap komitmen organisasional. Hasil penelitian juga menunjukkan bahwa terdapat pengaruh positif antara leader member exchange terhadap komitmen organisasional. Data dianalisis dengan menggunakan korelasi Multiple Linear Regression atau analisis regresi linear berganda melalui bantuan SPSS Statistics 25 for Windows.
\end{abstract}

Kata kunci: keadilan organisasi, leader member exchange, komitmen organisasional, karyawan

\section{The Effect of Organizational Justice and Leader member exchange on Organizational Commitments in Employees}

\begin{abstract}
Organizational commitment is an important element in the success of a company. Employees who have high commitment tend to show participation which is very influential for the progress of the company. The purpose of this study was to examine and determine the effect of organizational justice and leader member exchange on organizational commitment. The research sample consisted of 120 employees of PT. Maju Bersama Supermarkets with total sampling method. The research data were collected using a scale of organizational commitment, scale of organizational justice, and scale of leader member exchange. The results showed that there was an influence between organizational justice and leader member exchange on organizational commitment. The results showed that there was a positive influence between organizational justice and organizational commitment. The results also show that there is a positive influence between leader member exchanges on organizational commitment. Data were analyzed using Multiple Linear Regression correlation or multiple linear regression analysis with the help of SPSS Statistics 25 for Windows.
\end{abstract}

Keywords: organizational justice, leader member exchange, organizational commitment, employees

\section{Pendahuluan}

Pesatnya perkembangan industri di masa sekarang menyebabkan timbulnya persaingan yang sangat ketat. Hal inilah yang dapat membuat beberapa perusahaan mengalami peningkatan ataupun penurunan. Salah satu perusahaan yang sedang mengalami peningkatan pesat yaitu perusahaan ritel. Di Indonesia bisnis ini berkembang semakin pesat seiring dengan kemajuan perekonomian Indonesia. Menurut Utami (dalam 
Hikmawati \& Nuryakin, 2017) kata ritel berasal dari bahasa Perancis, "ritellier" yang berarti memotong atau memecah sesuatu. Asosiasi pengusaha ritel Indonesia (Aprindo) mengklaim pertumbuhan industri ritel pada semester I 2018 sebesar 7-7,5\%. Angka ini lebih besar dibandingkan pertumbuhan tahun 2017 yang hanya sebesar 5\% (CNBC Indonesia, 2018).

Elrehail et al., (2019) menuturkan sumber daya manusia dapat menjadi salah satu keunggulan kompetitif bagi perusahaan dalam bersaing. Menurut data dari Human Development Index (HDI) pada tahun 2010 menunjukkan kualitas sumber daya manusia di Indonesia menempati urutan ke 108 dari 152 negara di dunia (Mahesa Bhirawa, 2011). Hasil ini masih termasuk mengecewakan. Menurut Zopiatis dan Constanti (dalam Kristanto, 2015), sumber daya manusia akan menjadi beban bagi perusahaan apabila tidak dilakukan pengelolaan dengan tepat. Perusahaan bersaing dalam meningkatkan manajemen melalui struktur organisasi dengan menempatkan sumber daya manusia yang berkualitas dan berkompeten. Salah satu cara yang dapat dilakukan oleh perusahaan dalam mengelola sumber daya manusia ialah dengan memastikan bahwa terdapat semangat kerja, komitmen serta kepuasan pada karyawan itu sendiri (Tella et al., 2007). Menurut Zulkarnain dan Annisa (2013), karyawan akan memberikan apa yang ada dalam dirinya kepada organisasi, dan sebaliknya mereka juga akan menuntut supaya organisasi memberikan apa yang menjadi keinginannya.

Berdasarkan riset "Global Leadership Study" yang digagas oleh Dale Carnegie dengan melibatkan 3.300 pekerja dari 14 negara, yang menyertakan 205 karyawan dari Indonesia. Hasil riset menunjukkan 28\% karyawan di Indonesia memilih untuk bertahan dalam perusahaan. Sedangkan, lebih dari $30 \%$ tenaga kerja di Indonesia lebih memilih mencari pekerjaan baru (Mahesa Bhirawa, 2011). Alasannya, karyawan menuntut perusahaan untuk memberikan imbalan berupa gaji, fasilitas, status, keamanan kerja, penghargaan dan sebagainya. Bagi karyawan, imbalan yang diberikan perusahaan dapat memuaskan kebutuhan mereka, namun karyawan seringkali merasa bahwa perusahaan tidak dapat memenuhi kebutuhan tersebut. Karyawan yang bekerja di perusahaan tersebut merasa tidak puas dengan pekerjaan mereka dan sebagian memilih mencari pekerjaan baru. Suryani (2018) menuturkan bahwa dalam beberapa kasus, ditemukan kelompok milenial biasanya memiliki 4-5 pekerjaan berbeda sebelum mereka mencapai usia 25 tahun. Dampak dari permasalahan tersebut tidak hanya dirasakan oleh perusahaan, namun juga dirasakan karyawan yang memilih bertahan di perusahaan. Mereka mendapatkan beban kerja yang lebih berat apabila tidak ada karyawan baru yang bergabung di perusahaaan. Karyawan yang bertahan juga mengalami kesulitan dikarenakan mereka dituntut untuk membimbing dan beradaptasi dengan karyawan-karyawan yang baru bergabung dalam perusahaan. Saimir dan Jonida (2013) menemukan bahwa komitmen organisasi merupakan suatu kekuatan dari identifikasi seseorang terhadap keterlibatannya di dalam perusahaan. Pernyataan tersebut ditandai beberapa faktor seperti memiliki keyakinan tinggi dan bisa menerima norma-norma dan tujuan organisasi, bersedia untuk mengarahkan tenaga atas nama organisasi dan memiliki keinginan yang tinggi untuk tetap bertahan di organisasi.

Menurut Luthans (2011), komitmen organisasi merupakan sikap yang didefinisi sebagai keinginan kuat untuk tetap sebagai anggota organisasi tertentu, keinginan untuk berusaha keras sesuai keinginan organisasi, keyakinan tertentu dan penerimaan nilai dan tujuan organisasi. Beberapa faktor yang 
mempengaruhi komitmen organisasional seperti yang dikemukakan oleh David (dalam Sopiah, 2008) yaitu faktor personal misalnya usia, jenis kelamin, tingkat pendidikan, kepribadian, dan pengalaman kerja karyawan yang sangat berpengaruh terhadap komitmen karyawan pada organisasi. Karyawan yang baru beberapa tahun bekerja dan karyawan yang sudah puluhan tahun bekerja dalam organisasi tentu memiliki tingkat komitmen yang berbeda.

Menurut Pareke dan Suryana (dalam Putra \& Indrawati, 2018), perusahaan yang ingin mendapatkan komitmen yang tinggi dari karyawannya harus memperhatikan keadilan yang telah mereka terapkan dalam menjalankan perusahaan. Keadilan diperlakukan bagi semua karyawan, baik standardisasi pemberian gaji, perlakuan yang sama dari atasan kepada semua karyawan, penerapan aturan, dan instruksi bagi karyawan di perusahaan. Keadilan organisasi adalah istilah yang digunakan untuk menggambarkan peran keadilan yang secara langsung berkaitan dengan tempat kerja (Al-Zu'bi, 2010). Marissa (dalam Wiratama \& Suana, 2015) menyatakan keadilan organisasi merupakan suatu perlakuan, maupun tindakan yang diterima oleh setiap karyawan sama tanpa memandang status jabatan atau kedudukan dan dapat dikatakan adil apabila karyawan mendapatkan hak-hak mereka sesuai dengan apa yang mereka kontribusikan kepada perusahaan.

Keadilan dalam perusahaan memiliki peranan penting dikarenakan karyawan akan merasa puas dengan pekerjaannya sehingga terbentuk komitmen dalam diri karyawan. Hal ini dibuktikan dari penelitian yang dilakukan oleh Veress dan Gavreliuc (2018), bahwa keadilan organisasi dan komitmen organisasi merupakan dua konsep yang saling berhubungan satu sama lain yaitu melalui mediasi kepuasan kerja. Keadilan dalam organisasi juga penting bagi karyawan agar karyawan merasa menjadi bagian dari organisasi. Ketika karyawan merasa memiliki hubungan yang sama dengan karyawan lain dalam organisasi, mereka cenderung melihat diri mereka sendiri sebagai bagian dari organisasi (Imamoglu et al., 2019). Baik dalam hal pembagian gaji, perilaku manajer dan rekan kerja memengaruhi keputusan karyawan untuk melayani dan berjuang dengan tulus ataupun tidak bagi organisasi (Abubakr \& Majid, 2013). Penelitian ini dilatar belakangi oleh beberapa penelitian sebelumnya yang memperlihatkan bahwa terdapat kesenjangan mengenai pengaruh keadilan organisasi dan Leader Member Exchange (LMX) terhadap komitmen organisasional. Penelitian yang dilakukan oleh (Jawad et al., 2012) pada beberapa guru dari universitas yang berbeda menunjukkan bahwa terdapat pengaruh yang signifikan antara keadilan organisasional terhadap komitmen organisasi, Sedangkan penelitian yang dilakukan (Ghaziani et al., 2012) menunjukkan bahwa keadilan organisasi berpengaruh namun secara keseluruhan tidak memiliki jalur yang signifikan terhadap komitmen organisasional. Penelitian serupa juga dilakukan oleh (Hasan, 2019; Rejeki \& Wulansari, 2015) yang menunjukkan bahwa keadilan didalam organisasi tidak mempunyai pengaruh yang signifikan terhadap komitmen organisasi.

Tidak hanya keadilan yang memiliki kaitan dengan terbentuknya komitmen, namun hubungan antara atasan dan bawahan juga berperan penting dalam terbentuknya komitmen organisasional. Terjalinnya hubungan baik antara atasan dengan karyawan dapat mengarahkan atasan untuk memenuhi kebutuhan karyawan agar tercipta rasa bertanggung jawab dalam bekerja dan berusaha untuk mencapai tujuan perusahaan (Utami \& Zakiy, 2020). Leader Member Exchange (LMX) menurut Morrow (dalam Prisetyadi, 2011) adalah peningkatan kualitas hubungan antara supervisor dengan 
karyawan. Berdasarkan penelitian yang dilakukan oleh Nunes dan Gaspar (2017) pada 408 perawat menunjukkan bahwa Leader Member Exchange (LMX) berkorelasi signifikan terhadap berkembangnya komitmen organisasi. Akan tetapi bertolak belakang dengan hasil penelitian yang dilakukan oleh Estuning, (2010) pada karyawan bagian produksi yang menunjukkan bahwa Leader Member Exchange (LMX) berkorelasi negatif terhadap komitmen organisasional.

Komitmen organisasi penting untuk diteliti karena dengan adanya komitmen dalam diri karyawan maka akan menumbuhkan sikap ingin menetap yang dampaknya berpengaruh bagi keberhasilan organisasi dalam jangka panjang. Hal ini dibuktikan dengan penelitian yang dilakukan Leow dan Khong (2009) yang berjudul "Organizational Commitment : The Study of Organizational Justice and Leader Member Exchange ( LMX) Among Auditors in Malaysia", menyatakan bahwa variabel keadilan organisasi dan Leader Member Exchange ( $L M X)$ secara simultan mempunyai pengaruh yang signifikan terhadap komitmen organisasional.

Tujuan penelitian ini untuk menguji dan mengetahui pengaruh keadilan organisasi dan Leader Member Exchange (LMX) terhadap komitmen organisasional. Manfaat penelitian diharapkan dapat memberikan sumbangan kepada ilmu psikologi khususnya pada psikologi industri, untuk perusahaan dapat dijadikan bahan masukan dalam mengelola karyawan atau sumber daya manusia dengan baik di perusahaan tersebut. Adapun hipotesis yang akan diuji dalam penelitian ini diantaranya terdapat pengaruh antara keadilan organisasi dan Leader Member Exchange (LMX) terhadap komitmen organisasional (dapat dilihat pada bagan 1).

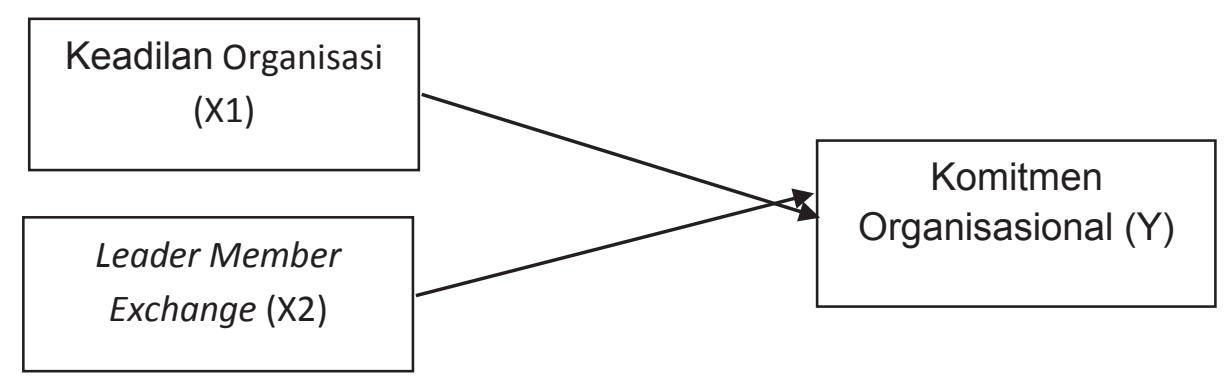

Bagan 1. Alur Hipotesis Penelitian

\section{Metode}

\section{Desain Penelitian dan Partisipan}

Penelitian ini merupakan penelitian kuantitatif yang bersifat asosiatif korelasional yaitu penelitian yang bertujuan untuk mengetahui pengaruh ataupun hubungan antara dua variabel atau lebih (Sugiyono, 2018). Penelitian ini melibatkan 3 variabel yaitu variabel terikat $(Y)$ adalah komitmen organisasional. Menurut Sugiyono (2018), variabel terikat merupakan variabel yang dipengaruhi atau menjadi akibat karena adanya variabel bebas. Variabel bebas (X1) adalah keadilan organisasi, dan variabel bebas (X2) adalah leader member exchange. Definisi variabel bebas menurut Sugiyono (2018) adalah variabel yang mempengaruhi atau yang menjadi sebab perubahan variabel terikat. Teknik pengambilan sampel dengan menggunakan teknik total sampling. Dengan menggunakan total sampling, maka populasi yang digunakan dalam penelitian ini adalah seluruh karyawan di PT. Pasar Swalayan Maju Bersama Yos Sudarso Medan dengan jumlah subjek sebanyak 120 orang. 


\section{Pengukuran}

Metode pengumpulan data menggunakan skala komitmen organisasional, skala keadilan organisasi, dan skala leader member exchange. Tersedia empat pilihan jawaban yaitu SS (Sangat Sesuai), S (Sesuai), TS (Tidak Sesuai), dan STS (Sangat Tidak Sesuai). Skala komitmen organisasional diukur berdasarkan dimensi yang dikemukakan oleh Meyer, Allen, dan Smith (dalam Sopiah, 2008), yaitu: affective commitment (komitmen afektif), continuance commitment (komitmen berkelanjutan), normative commitment (komitmen normatif). Variabel ini terdiri dari 42 aitem pernyataan, dengan 21 aitem pernyataan favourable dan 21 aitem pernyataan unfavourable. Azwar (2014) menyatakan bahwa jika koefisien validitas (r) lebih dari 0,30 biasanya dianggap memuaskan. Uji validitas ini menggunakan metode corrected item total correlation, di mana aitem yang sahih sebanyak 36 aitem dapat dilihat berdasarkan nilai $r$ minimal 0,30 . Pada pengujian reliabilitas digunakan teknik Alpha Cronbach.Pada skala komitmen organisasional diperoleh koefisien reliabilitas Alpha Cronbach sebesar 0.922. Hal tersebut menunjukkan bahwa skala ini layak digunakan sebagai alat pengumpulan untuk data penelitian.

Skala keadilan organisasi diukur berdasarkan dimensi yang dikemukakan Moorman (dalam Bela \& Rahardjo, 2014), yaitu tingkat pemberian kompensasi, tingkat keadilan dalam pemberian beban kerja, tingkat keterlibatan dalam pengambilan keputusan dan, tingkat keadilan dalam pemberian tanggung jawab. Variabel ini terdiri dari 48 aitem pernyataan, dengan 24 aitem pernyataan favourable dan 24 aitem pernyataan unfavourable. Azwar (2014) menyatakan bahwa jika koefisien validitas (r) lebih dari 0,30 biasanya dianggap memuaskan. Uji validitas ini menggunakan metode corrected item total correlation, di mana aitem yang sahih sebanyak 29 aitem dapat dilihat berdasarkan nilai $r$ minimal 0,30 . Pada pengujian reliabilitas digunakan teknik Alpha Cronbach. Pada skala keadilan organisasi diperoleh koefisien reliabilitas Alpha Cronbach sebesar 0,910. Hal tersebut menunjukkan bahwa skala ini layak digunakan sebagai alat pengumpulan untuk data penelitian.

Skala leader member exchange diukur berdasarkan dimensi yang dikemukakan oleh Yukl (2010), yaitu mutual trust, respect, affection, support, loyalty. Variabel ini terdiri dari 50 aitem pernyataan, dengan 25 aitem pernyataan favourable dan 25 aitem pernyataan unfavourable. Azwar (2014) menyatakan bahwa jika koefisien validitas (r) lebih dari 0,30 biasanya dianggap memuaskan. Uji validitas ini menggunakan metode corrected item total correlation, di mana aitem yang sahih sebanyak 33 aitem dapat dilihat berdasarkan nilai $r$ minimal 0,30. Pada pengujian reliabilitas digunakan teknik Alpha Cronbach. Pada skala leader member exchange diperoleh koefisien reliabilitas Alpha Cronbach sebesar 0,901.

\section{Analisis Data}

Dalam penelitian ini teknik analisis data yang digunakan teknik analisis regresi berganda dengan bantuan analisis program SPSS (Statistical Package for the Social Sciences) 25.00 for Windows. Analisis regresi berganda digunakan untuk menaksir atau meramalkan nilai variabel dependen, yang mana variabel independen lebih dari satu (Priyatno, 2011). Metode ini digunakan untuk mengetahui pengaruh keadilan organisasi dan leader member exchange terhadap komitmen organisasional yang dimiliki oleh karyawan.

\section{Hasil}

Hasil Analisis Deskriptif Data 
Tabel 1. Perbandingan Data Empirik dan Hipotetik

\begin{tabular}{|c|c|c|c|c|c|c|c|c|}
\hline \multirow{2}{*}{ Variabel } & \multicolumn{3}{|c|}{ Empirik } & \multirow{2}{*}{ SD } & \multicolumn{3}{|c|}{ Hipotetik } & \multirow{2}{*}{ SD } \\
\hline & Min & Max & Mean & & Min & Max & Mean & \\
\hline $\begin{array}{l}\text { KOMITMEN } \\
\text { ORGANISASIONAL }\end{array}$ & 77 & 132 & 100,51 & 10,068 & 36 & 144 & 90 & 18 \\
\hline $\begin{array}{l}\text { KEADILAN } \\
\text { ORGANISASI }\end{array}$ & 68 & 112 & 89,37 & 11,059 & 29 & 116 & 72,5 & 14,5 \\
\hline LMX & 59 & 126 & 97,45 & 13,850 & 33 & 132 & 82,5 & 16,5 \\
\hline
\end{tabular}

Deskripsi data dalam penelitian ini mencakup skor empirik dan skor hipotetik. Hasil analisis untuk skala komitmen organisasional diperoleh mean empirik > mean hipotetik yaitu 100,51 > 90 maka dapat disimpulkan bahwa komitmen organisasional pada subjek penelitian lebih tinggi daripada populasi pada umumnya. Hasil analisis untuk skala keadilan organisasi diperoleh mean empirik > mean hipotetik yaitu 89,37 > 72,5 maka dapat disimpulkan bahwa keadilan organisasi pada subjek penelitian lebih tinggi daripada populasi pada umumnya. Hasil analisis untuk skala leader member exchange diperoleh mean empirik > mean hipotetik yaitu 97,45 > 82,45 maka dapat disimpulkan bahwa leader member exchange pada subjek penelitian lebih tinggi daripada populasi pada umumnya.

Hasil uji asumsi klasik

\section{Uji Normalitas}

Data dapat dikatakan normal jika $p>0.05$ (Priyatno, 2011). Hasil uji normalitas yang telah dilakukan diperoleh koefisien KS-Z $($ Test Statistic $)=0.081$ dengan sig. sebesar 0.053 untuk uji 2 (dua) arah ( $p>0.05$ ), yang berarti bahwa nilai residual terdistribusi secara normal.

\section{Uji Multikolinearitas}

Uji multikolinearitas dilakukan untuk menguji apakah dalam regresi ditemukan adanya korelasi antar variabel independen. Hal ini dapat dilakukan dengan melihat nilai tolerance dan nilai Variance Inflation Factor (VIF) dengan kriteria sebagai berikut: Jika nilai tolerance $>0.10$ atau nilai VIF $<10$, berarti terjadi multikolinearitas (Priyatno, 2011). Berdasarkan hasil uji multikolinearitas, nilai VIF dari variabel keadilan organisasi adalah 2.143 dan nilai VIF dari variabel LMX adalah 2.143. Masing-masing nilai VIF tidak lebih besar dari 10, maka tidak terdapat gejala multikolinearitas yang berat. Berdasarkan hasil tersebut membuktikan bahwa tidak terjadi korelasi antara variabel bebas yang signifikan.

\section{Uji Autokorelasi}

Tujuan dari uji autokorelasi adalah untuk mengetahui apakah dalam model regresi linear terjadi korelasi residual untuk pengamatan satu dengan pengamatan lain yang disusun menurut runtun waktu (Priyatno, 2011). Hasil yang diperoleh dari uji tersebut diperoleh nilai statistik Durbin-Watson adalah $\mathrm{du}(1.733)<\mathrm{dw}(2.052)<4-\mathrm{du}(2.266)$, maka asumsi non-autokorelasi terpenuhi.

\section{Uji Heteroskedastisitas}

Pengujian heteroskedastisitas dapat menggunakan teknik uji koefisien korelasi spearman's rho, yaitu mengorelasikan variabel independen dengan residualnya. Apabila antara variabel independen dengan residual diperoleh signifikansi lebih dari 0.05 maka tidak terjadi heteroskedastisitas (Priyatno, 2011). Berdasarkan tabel di atas, nilai signifikansi dari keadilan organisasi $(p=0.673)$ dan LMX $(p=0.577)$ adalah 
lebih besar dari 0.05. Dikarenakan nilai signifikansi lebih besar dari 0.05 , maka dapat disimpulkan bahwa tidak terjadi masalah heteroskedastisitas.

\section{Hasil Uji Hipotesis}

Uji hipotesis yang digunakan dalam penelitian ini adalah teknis analisis regresi berganda. Hasil regresi diperoleh hasil hipotesa mayor, terdapat pengaruh antara keadilan organisasi dan leader member exchange terhadap komitmen organisasional yang dinyatakan dengan nilai $\mathrm{F}=49.087$ dan $\mathrm{p}=0.000(\mathrm{p}<0.05)$, namun nilai Adjusted $R$ Square $=0.447$ yang berarti keadilan organisasi dan leader member exchange memberikan sumbangan efektif sebesar 44,7 persen terhadap komitmen organisasional dan sisanya 55.3 persen dipengaruhi oleh faktor lain yang tidak diteliti.

Tabel 2. Hasil Analisis Regresi Berganda

\begin{tabular}{cccccc}
\hline Model & Sum of Squares & Df & Mean Square & F & Sig. \\
\hline Regression & 5503,354 & 2 & 2751,677 & 49,087 &, $000^{\mathrm{b}}$ \\
Residual & 6558,637 & 117 & 56,057 & & \\
Total & 12061,992 & 119 & & & \\
\hline
\end{tabular}

Hasil analisis dari hipotesis minor dapat disimpulkan bahwa :

a. Terdapat pengaruh positif antara keadilan organisasi terhadap komitmen organisasional dengan nilai $p=0.000$ $(p<0.05)$ dan $\beta=0.455$ yang berarti hipotesis diterima.

b. Terdapat pengaruh positif antara leader member exchange terhadap komitmen organisasional dengan nilai $p=0.008$ $(p<0.05)$ dan $\beta=0.268$ yang berarti hipotesis diterima.

Tabel 3. Hasil Analisis Nilai $\beta$ Korelasi

\begin{tabular}{ccc}
\hline Variabel & $\boldsymbol{\beta}$ & Sig. \\
\hline Keadilan Organisasi & 0.455 & 0.000 \\
LMX & 0.268 & 0.008 \\
\hline
\end{tabular}

\section{Pembahasan}

Hasil penelitian ini membuktikan bahwa keadilan organisasi mempengaruhi komitmen organisasional. Hasil penelitian ini mendukung hasilpenelitianyang dilakukan (Buluc\& Gunes, 2014) menyatakan bahwa variabel keadilan didalam organisasi mempunyai pengaruh terhadap komitmen organisasi. Dalam penelitiannya dijabarkan bahwa pemimpin harus berperilaku adil dan melakukan yang terbaik untuk memenuhi kebutuhan karyawan. Persepsi tersebut mempengaruhi komitmen organisasi, keperca-yaan organisasi dan sebagainya. Merujuk pada penelitian tersebut maka keadilan berperan penting untuk keberhasilan dan kesejateraan organisasi melalui adanya komitmen dari karyawan. Namun terdapat hal yang menarik pada hasil penelitian yang dilakukan oleh (Ghaziani et al., 2012; Hasan, 2019; Rejeki \& Wulansari, 2015) yang menunjukkan bahwa keadilan organisasi berpengaruh terhadap komitmen organisasional tetapi hasilnya tidak signifikan. Menurut Hair et.al (dalam Hasan 2019), pengaruh yang tidak signifikan kemungkinan dikarenakan oleh karyawan yang tidak menjadikan masalah perlakuan yang disampaikan oleh perusahaan dan rasa keadilan yang mereka terima selama bekerja. 
Sedangkan hasil penelitian yang dilakukan oleh (Diatmono, 2019; Dorji \& Kaur, 2019; Galavandi et al., 2015; Karem et al., 2019; Kumari \& Afroz, 2013; Rahman et al., 2016; Saldanha et al., 2019; Wiyati Mahrani et al., 2013), mengemukakan bahwa ada dampak signifikan keadilan organisasi terhadap komitmen organisasi. Menurut (Nurcahyani \& Mas'ud, 2016), ketika karyawan diperlakukan secara adil, karyawan akan semakin meningkatkan komitmennya terhadap organisasi yang ditunjukkan dengan perilaku dan sikap positif terhadap organisasi karena merasa senang dan nyaman dalam bekerja. Hal ini juga sejalan dengan penelitian yang dilakukan oleh (Suwandewi \& Sintaasih, 2016) bahwa semakin baik keadilan organisasional yang dirasakan karyawan maka komitmen organisasional yang dimiliki oleh karyawan akan semakin meningkat. Dalam penelitian ini juga ditemukan bahwa karyawan yang merasa diperlakukan secara adil cenderung menunjukkan sikap yang sukarela dalam bekerja dan merasakan dirinya memiliki tanggung jawab dalam pekerjaan tersebut. Hal ini mendukung penelitian yang dilakukan oleh Andrew dan Dennis (2019) mengenai keadilan organisasi dan komitmen karyawan pada staff di University Of Benin yang menyatakan bahwa keadilan distributif harus dipraktikkan dalam pendidikan industri sehingga dapat meningkatkan tingkat komitmen karyawan. Keadilan yang dimaksud, diantaranya keadilan dalam pemberian kompensasi, pemberian beban kerja, atasan memperlakukan karyawan dengan cara yang baik, menghargai pendapat karyawan pada saat pengambilan keputusan, dan keadilan dalam pemberian tanggung jawab.

Adanya keterlibatan timbal balik yang baik antara atasan dan bawahan juga membentuk komitmen pada karyawan. (Taqiuddin et al., 2018) menuturkan bahwa ketika atasan berusaha menjaga rasa puas bawahannya, sering meminta ide atau pendapat dari karyawan, akan membuat suasana kekeluargaan dalam bekerja sehingga karyawan merasa nyaman dan terbentuklah komitmen. Hasil yang diperoleh dari penelitian ini menunjukkan bahwa leader member exchange memiliki pengaruh terhadap komitmen organisasional. Penelitian ini sejalan dengan penelitian yang dilakukan oleh (Saputra \& Ariyanto, 2019) yang menunjukkan bahwa leader member exchange memberikan pengaruh yang signifikan terhadap komitmen organisasional. Dalam penelitiannya dijabarkan bahwa ketika seorang karyawan merasa hubungannya baik dengan atasannya maka ia akan merasa nyaman dalam bekerja sehingga memiliki keinginan untuk terus berkarya di organisasi dan hal ini akan membuat komitmen karyawan terhadap organisasi meningkat. Atasan perlu menyadari cara mereka memperlakukan bawahan agar bawahan dapat menunjukkan kinerja yang lebih baik untuk organisasi dan memiliki komitmen yang tinggi (Strukan \& Nikolić, 2017). Sikap saling menghormati antara atasan dan bawahan mampu meningkatkan perasaan emosional, keterikatan, identifikasi dan keterlibatan pegawai pada organisasi (Strukan \& Nikolić, 2017). Dalam penelitian ini juga ditemukan bahwa karyawan yang mendapatkan perlakuan baik dari atasan cenderung merasa dirinya lebih dihargai dan diakui dalam perusahaan sehingga memotivasi karyawan untuk lebih giat bekerja demi mengembangkan perusahaan. Karyawan juga cenderung dapat menerima norma-norma di perusahaan. Penelitian yang dilakukan oleh (Garg \& Dhar, 2014; López-lbort et al., 2020; Nunes \& Gaspar, 2017; Sasmita \& Supriyadinata, 2019) menunjukkan bahwa leader member exchange berpengaruh terhadap komitmen organisasional. Prisetyadi (2011) menyatakan bahwa hubungan pertukaran antara atasan dan bawahan yang dapat dikarakteristikkan dengan adanya saling percaya, saling menghargai, saling menyukai, dan saling mempengaruhi antara pimpinan dengan 
bawahan sangat baik. Sejalan dengan penelitian yang dilakukan oleh (Taupan et al., 2015) menyatakan bahwa variabel affect, loyalty, contribution, dan professional respect berkorelasi secara signifikan terhadap variabel komitmen organisasional.

Berdasarkan penjelasan di atas dapat disimpulkan bahwa Komitmen organisasi merupakan salah satu elemen penting dalam keberhasilan sebuah perusahaan. Karyawan yang memiliki komitmen tinggi cenderung menunjukkan partisipasi yang sangat berpengaruh bagi kemajuan perusahaan (Suryani, 2018). Berdasarkan hasil penelitian ini dapat dibuktikan bahwa terdapat pengaruh antara keadilan organisasi dan leader member exchange terhadap komitmen organisasional. Penelitian ini mendukung penelitian yang dilakukan oleh (Leow \& Khong, 2009) yang menyatakan bahwa semua variabel independen leader member exchange dan keadilan organisasi secara simultan mempunyai pengaruh yang signifikan terhadap variabel dependen (komitmen organisasional). Penelitian yang sejalan juga dilakukan oleh (Bela \& Rahardjo, 2014) menunjukkan bahwa leader member exchange memberikan pengaruh terhadap komitmen organisasional. Perusahaan yang mampu menciptakan dan menjaga kepuasan kerja karyawan dapat mendorong karyawan untuk menghasilkan kinerja yang baik dan memiliki komitmen yang tinggi.

Dalam penelitian ini menunjukkan bahwa karyawan cenderung merasa puas dengan perusahaan, apabila diberikan perlakuan yang lebih dari yang diharapkan, seperti mendapatkan perlakuan yang adil dari perusahaan dan memiliki hubungan yang baik antara atasan dan bawahan sehingga membentuk komitmen dalam diri karyawan. Atasan yang cenderung melibatkan bawahan dalam urusan di perusahaan juga menunjukkan bahwa atasan dan bawahan memiliki hubungan pertukaran yang berkualitas. Dengan adanya hubungan pertukaran yang berkualitas, maka akan meningkatkan rasa kepercayaan, sikap toleransi, saling mendukung, menghargai, dan meningkatnya loyalitas karyawan. Dampaknya akan menurunkan tingkat turnover pada karyawan, karena karyawan memiliki komitmen terhadap perusahaan. Hal ini sejalan dengan wawancara yang dilakukan pada karyawan PT. Pasar Swalayan Maju Bersama yang menyatakan bahwa ketika perusahaan memberikan perlakuan yang adil terhadap semua karyawan, baik dalam pembagian upah, beban kerja, keterlibatan dalam pengambilan keputusan, dan pembagian tanggung jawab serta apabila karyawan dilibatkan dalam setiap urusan yang ada di perusahaan, karyawan akan lebih merasa nyaman dan puas bekerja di perusahaan tersebut. Alasannya, karena karyawan merasa bahwa keterlibatan mereka berpengaruh bagi perusahaan. Hal ini juga akan membuat karyawan lebih peduli terhadap perusahaan dan membuat karyawan terus berusaha mengembangkan perusahaan kearah yang lebih baik.

Keterbatasan penelitian ini adalah pertama, terbatasnya jumlah subjek penelitian. Subjek penelitian ini hanya mengambil dari salah satu cabang di perusahaan tersebut, sehingga belum mencakup semua karyawan yang ada di perusahaan. Peneliti selanjutnya dapat memilih lokasi penelitian yang lebih luas untuk mengjangkau lebih banyak lagi subjek penelitian. Kedua, waktu penelitian yang terbatas. Peneliti selanjutnya diharapkan dapat menggunakan waktu yang lebih tepat dan tidak terburu-buru.

\section{Kesimpulan}

Berdasarkan hasil penelitian, dapat disimpulkan bahwa terdapat pengaruh antara keadilan organisasi dan leader member exchange terhadap komitmen organisasional. Implikasi dari penelitian ini 
bagi perusahaan diharapkan dapat lebih meningkatkan rasa kepedulian kepada karyawan dengan berusaha untuk selalu melibatkan karyawan dalam setiap kegiatan sehingga dapat meningkatkan komitmen, sesuai dengan tugas pokok dan fungsinya. Untuk menghasilkan produksi yang baik, juga diperlukan komunikasi yang lebih efektif antara atasan dengan bawahan.

\section{Daftar Pustaka}

Abubakr, S., \& Majid, A. K. (2013). Organizational Justice, Commitment And Performance In Developing Countries: The Case Of The UAE. Employee Relations, 35(1), 98-115. https://doi. org/10.1108/01425451311279438

Al-Zu'bi, H. A. (2010). A Study of Relationship between Organizational Justice and Job Satisfaction. International Journal of Business and Management, 5(12). https://doi.org/10.5539/ijbm.v5n12p102

Andrew, E., \&Dennis, O. (2019). Organizational Justice And Employee Commitment: Evidence From University Of Benin. International Journal of Economics and Management Studies, 6(7), 84-91. https://doi.org/10.14445/23939125/ ijems-v6i7p113

Azwar, S. (2014). Metode Penelitian. Yogyakarta: Pustaka Belajar.

Bela, A. N., \& Rahardjo, M. (2014). Pengaruh Leader Member Exchange ( Lmx ) Dan Keadilan Organisasi Terhadap Komitmen Organisasional ( Studi empiris pada karyawan Rumah Sakit Bhakti Asih Brebes ). Diponegoro Journal Of Management, 3(4), 1-14.

Buluc, B., \& Gunes, A. M. (2014). Relationship Between Organizational Justice And Organizational Commitment In Primary Schools. Anthropologist, 18(1), 145152. https://doi.org/10.1080/09720073.2 014.11891530

CNBC Indonesia. (2018, June22). Pengusaha:
Industri Ritel Semester I-2018 Tumbuh 7-7,5\%. https://www.cnbcindonesia. com/news/20180622163406-4-20125/ pengusaha-industri-ritel-semester-i2018-tumbuh-7-75

Diatmono, P. (2019). Influence of Organizational Justice, Leadership Behavior, Trust Employee and Job Satisfaction To Organization Commitment of Pt. Bram. Business and Entrepreneuarial Review, 17(2), 105. https://doi.org/10.25105/ber. v17i1.5164

Dorji, C., \& Kaur, K. (2019). The Impact Of Organizational Justice On Organizational Commitment: A Perception Study On Teachers of Bhutan. International Journal of Recent Technology and Engineering, 7(6S5), 436-440.

Elrehail, H., Harazneh, I., Abuhjeeleh, M., Alzghoul, A., Alnajdawi, S., \& Ibrahim, H. M. H. (2019). Employee satisfaction, human resource management practices and competitive advantage: The case of Northern Cyprus. European Journal of Management and Business Economics, 29(2), 125-149. https://doi.org/10.1108/ EJMBE-01-2019-0001

Estuning, R. (2010). Komitmen Organisasi ditinjau dari Kepuasan Kerja dan Hubungan Atasan - Bawahan. Skripsi Universitas Katolik Soegijapranata Semarang.

Galavandi, H., Alizadeh, M., Ebrahim, M., \& Naghipour, K. (2015). The relationship between perceived organizational justice and organizational commitment: A case study of female teachers. International Journal of Educational and Psychological Researches, 1(2), $80 . \quad$ https://doi. org/10.4103/2395-2296.152219

Garg, S., \& Dhar, R. L. (2014). Effects of stress, LMX and perceived organizational support on service quality: Mediating effects of organizational commitment. Journal of Hospitality and Tourism Management, 21, 64-75. https://doi. 
org/10.1016/j.jhtm.2014.07.002

Ghaziani, F. G., Safania, A., \& Tayebi, S. M. (2012). Impact of organizational justice perceptions on job satisfaction and organizational commitment: The Iran's ministry of sport perspective. Australian Journal of Basic and Applied Sciences, 6(7), 179-188.

Hasan, G. (2019). Motivasi, Kepuasan, Karakteristik, Kepemimpinan dan Keadilan Terhadap Komitmen Organisasi. Efisiensi - Kajian IImu Administrasi, 16(1), 2132. https://doi.org/10.21831/efisiensi. v16i1.24474

Hikmawati, D., \& Nuryakin, C. (2017). Keberadaan Ritel Modern dan Dampaknya terhadap Pasar Tradisional di DKI Jakarta. Jurnal Ekonomi Dan Pembangunan Indonesia, 17(2), 195208. $\quad$ https://doi.org/10.21002/jepi. v17i2.768

Imamoglu, S.Z., Ince, H., Turkcan, H., \&Atakay, B. (2019). The Effect of Organizational Justice and Organizational Commitment on Knowledge Sharing and Firm Performance. Procedia Computer Science, 158, 899-906. https://doi. org/10.1016/j.procs.2019.09.129

Jawad, M., Raja, S., Abraiz, A., \& Tabassum, T. M. (2012). Role of Organizational justice in organizational commitment with moderating effect of employee work attitudes. IOSR Journal of Business and Management, 5(4), 39-45. https://doi. org/10.9790/487x-0543945

Karem, M. A., Jameel, A. S., \& Ahmad, A. R. (2019). The impact of organizational justice dimensions on organizational commitment among bank employees. International Journal of Psychosocial Rehabilitation, 23(2), 502-513.

Kristanto, H. (2015). Keadilan Organisasional, Komitmen Organisasional, Dan Kinerja Karyawan. Jurnal Manajemen Dan Kewirausahaan (Journal of Management and Entrepreneurship), 17(1), 86-98. https://doi.org/10.9744/jmk.17.1.86-98

Kumari, N., \& Afroz, N. (2013). The impact of organizational justice on organizational commitment and creative behaviour among thermal power Industrial employees. IOSR Journal Of Humanities And Social Science, 16(6), 01-06. https://doi.org/10.9790/0837-1660106

Leow, K. L., \& Khong, K. W. (2009). Organizational Commitment : The Study of Organizational Justice and Leader Member Exchange ( LMX ) Among Auditors in Malaysia. International Journal of Business and Information, 4(2), 161-198.

López-lbort, N., González-De la Cuesta, D., Antoñanzas-Lombarte, T., \& GascónCatalán, A. (2020). The correlation between leader-member exchange and organisational commitment among spanish registered nurses: The moderating role of sex and hospital size. International Journal of Environmental Research and Public Health, 17(3). https://doi.org/10.3390/ijerph17030721

Luthans, F. (2011). Organizational Behavior: An Evidence-Based Approach (Twelfth Ed). McGraw-Hill.

Mahesa Bhirawa. (2011, March 14). Kualitas SDM Indonesia di Dunia. https://www. kompasiana.com/hesabhirawa/55009 5bea333111773511436/kualitas-sdmindonesia-di-dunia

Nunes, E. M. G. T., \& Gaspar, M. F. M. (2017). A qualidade da relação líder-membro e o empenhamento organizacional dos enfermeiros. Revista Da Escola de Enfermagem Da USP, 51(0), 1-6. https://doi.org/10.1590/s1980-220x 2016047003263

Nurcahyani, D., \& Mas'ud, F. (2016). Pengaruh Keadilan Organisasional Terhadap Komitmen Organisasi Dengan Jarak Kekuasaan Sebagai Variabel Moderating (Studi pada PT. PLN (Persero) APJ Semarang). Diponegoro 
Journal Of Management, 5(3), 1-11. http://ejournal-s1.undip.ac.id/index.php/ $\mathrm{dbr}$

Prisetyadi, A. (2011). Pengaruh Leader Member Exchange Terhadap Komitmen. Manajemen Bisnis, 1(1), 1-6.

Priyatno, D. (2011). Buku Saku Analisis Statistik Data SPSS. MediaKom.

Putra, I., \& Indrawati, A. (2018). Pengaruh Keadilan Organisasi terhadap Kepuasan Kerja dan Komitmen Organisasional di Hotel Rama Phala Ubud. E-Jurnal Manajemen Universitas Udayana, 7(4), 255368. https://doi.org/https://doi. org/10.24843/EJMUNUD.2018.v7.i04. p11

Rahman, A., Shahzad, N., Mustafa, K., Khan, M. F., \& Qurashi, F. (2016). Effects of organizational justice on organizational commitment. International Journal of Economics and Financial Issues, 6(3), 188-196.

Rejeki, A. T., \& Wulansari, N. A. (2015). Pengaruh Keadilan Organisasional Pada Komitmen Organisasional dengan Kepuasan Kerja Sebagai Variabel Intervening. Management Analysis Journal, 4(4), 319-326.

Saimir, S., \& Jonida, L. (2013). Job Satisfaction and Organizational Commitment: the Case of Shkodra Municipality. European Scientific Journal, 9(17), 41-51.

Saldanha, L. D. S., Supartha, W. G., \& Riana, G. (2019). Pengaruh Keadilan Organisasional Terhadap Kepuasan Kerja Dan Komitmen Organisasional Polícia Nacional De Timor-Leste (Pntl). E-Jurnal Ekonomi Dan Bisnis Universitas Udayana, 2, 137. https://doi. org/10.24843/eeb.2019.v08.i02.p02

Saputra, A., \& Ariyanto, E. (2019). the Effect of Leader Member Exchange, Job Satisfaction and Motivation on Educational Personnels' Organizational Commitment of Jakarta Mercu Buana University. International Review of
Management and Marketing, 9(6), 5866. https://doi.org/10.32479/irmm.8650 Sasmita, P. L. G. D., \& Supriyadinata, G. A. A. N. E. (2019). Influence of Job Satisfaction and Organizational Commitment on Leader Member Exchange and Empowerment of Behavior in Organization. Russian Journal of Agricultural and Socio-Economic Sciences, 94(10), 79-86. https://doi.org/10.18551/ rjoas.2019-10.10

Sopiah. (2008). Perilaku Organisasional. Andi Offset.

Strukan, E., \& Nikolić, M. (2017). Research on the impact of LMX leadership theory on mutual trust and organisational commitment of employees in Bosnia and Herzegovina. IOP Conference Series: Materials Science and Engineering, 200(1). $\quad$ https://doi.org/10.1088/1757899X/200/1/012004

Sugiyono. (2018). Metode Penelitian Pendidikan Pendekatan Kuantitatif, Kualitatif, Dan R \& D. Alfabeta.

Suryani, I. (2018). Factors Affecting Organizational Performance. Jurnal Manajemen Dan Inovasi, 9(1), 26-34. https:// doi.org/10.24312/paradigms050102

Suwandewi, N. N. T., \& Sintaasih, D. (2016). Keadilan Organisasional Dan Komitmen Organisasional: Efeknya Pada Organizational Citizenship Behavior. E-Jurnal Manajemen Universitas Udayana, 5(7), 253727.

Taqiuddin, H., Tricahyadinata, I., \& Sampeliling, A. (2018). Pengaruh Leader Member Exchange dan Komitmen Organisasi Terhadap Kinerja Karyawan Teladan Prima Group Kota Samarinda. Forum Ekonomi, 20(2), 111-122.

Taupan, F., Sunyoto, C., \& Wijaya, K. (2015). Hubungan Leader-Member Exchange Dan Komitmen Organisasional: Studi Pada Karyawan Restoran D'cost Seafood Surabaya. Journal Of Universitas Kristen Petra, 1(147), 147-158. 
Tella, A., Ayeni, C. O., \& S. O. Popoola, P. D. (2007). Work Motivation, Job Satisfaction , and Organisational Commitment of Library Personnel in Academic and Research Libraries in Oyo State ,. Department of Library Archival and Information Studies Faculty of Education University of Ibadah, Nigeria, 2(April), 1-16.

Utami, V. P., \& Zakiy, M. (2020). Linking Leader Member Exchange And Person Supervisor Fit With Employee Performance: The Mediating Role Of Employee Work Engagement. Journal of Leadership in Organizations, 2(2), 121-137.

Veress, Z. E., \& Gavreliuc, A. (2018). Organizational Commitment, Organizational Justice and Work Satisfaction: A Comprehensive Model in a Romanian Organizational Setting. Romanian Journal of Applied Psychology, 20(2), 60-69. https://doi.org/10.24913/rjap.20.2.05

Wiratama, D. G., \& Suana, I. wayan. (2015). Pengaruh keadilan organisasi terhadap kepuasan kerja dan. 4(11), 3675-3702.

Wiyati Mahrani, S., Kamaluddin, M., \& Syaifuddin, D, T. (2013). www.ijsr.net Organizational Justice and Organizational Commitment. International Journal of Science and Research (IJSR), 14(3), 2319-7064.

Yukl, G. (2010). Leadership in Organizations (seventh ed). Pearson Education, Inc.

Zulkarnain, \& Annisa. (2013). Komitmen Terhadap Organisasi Ditinjau Dari Kesejahteraan Psikologis Pekerja. INSAN, 15(1), 54-62. 